\title{
THE STUDY OF RELIGION IN THE DEPARTMENT OF SOCIAL AND CULTURAL ANTHROPOLOGY, VRIJE UNIVERSITEIT AMSTERDAM
}

\author{
André Droogers \\ Marjo de Theije \\ Peter Versteeg ${ }^{1}$
}

\begin{abstract}
The authors of this article analyze the trajectory and the contemporary moment of a group of professors and researchers in Anthropology of Religion at the Department of Social Anthropology at Free University of Amsterdam. They elaborate a brief history of the constitution of the group in second half of the 20th Century. In the decades of 1960 and 1970, the field researches were developed in different locals in the world, with theoretical marks also different. Nowadays there is an articulation of the researches of the professors and $\mathrm{PhD}$ students in two big programs. The first: "Between secularization and sacralization", includes researches on the Dutch religious field from a qualitative methodological grade. The second: "Careers of conversion and politics of culture", is dedicated on the study of the expansion of charismatic and pentecostal Christianity in Holland and over the globe.
\end{abstract}

Keywords: social research and religion, secularization. pentecostalism, Free University of Amsterdam.

The Department of Social and Cultural Anthropology of the Vrije Universiteitin Amsterdam has a long tradition in the study of religion. Over the years and decades the focus has shifted several times, as the researchers involved changed and the impetus from the wider disciplinary group varied, institutionalopportunities appeared and disappeared and theoretical concerns diversified and followed modifications in the wider disciplinary field. In this article we will give a short overview of the history of the study of religion in the department, thereby highlighting the role of the chair of Anthropology

\footnotetext{
${ }^{1}$ They are professors at the Free University of Amsterdam, Holland.
} 
of Religion. Wewill also pay special attention to two large research programs currently in progress.

\section{HISTORICAL OVERVIEW}

The department was founded at the beginning of the sixties. From the very start religion was on the agenda. This was partly the case because the Vrije Universiteit was founded (1880) within the context of the Dutch Reformed Churches, which stimulated interest in the relationship between scienceand religion. On the other hand, in the early days of this anthropology department some scholars were recruited who had in some way worked in a Christian missionary context in Indonesia (formerly the Dutch Indies) and had discovered the importance of the study of religion. As a consequence a chair was established for the anthropologyof religion, Johan Blauw, a former secretary of the Dutch Mission Council, being its first occupant. But other staff members were interested in religious themes as well. The research focus of the department reflected this interest. Thus at the end of the sixties the theme of Christian groups in the Third World was chosen. In the eighties Religion and Power became the theme. Practically this meant that staff members and $\mathrm{PhD}$ candidates sought to do research on concrete issues that contributed to the knowledge of the general theme.

Staff members differed in their way of dealing with religion, depending on the region they workedin and the theoretical framework that was adopted. Professor Herman Schulte Nordholt had written his thesis on the religious and symbolic system of the inhabitants of the Indonesian island of Timor. He worked along structuralist lines, besides following the insights of the Leyden school. Also as a professor he stimulated research on religious issues. Equally situated in Indonesia was the work Reimar Schefold did on the island of Siberut,working along similar lines. Schefoldlater became professor of Indonesia studies in Leyden. Johannes Tennekes went to Chile for an innovating study of Pentecostal churches. Pentecostalism became a continuous interest under his guidance, especially after he became professor of cultural anthropology as Schulte Nordholt's successor. Philip Quarles

Debates do NER, Porto Alegre, Ano 8, N. 11, P. 83-93, JAN./Jun. 2007 
van Ufford worked in the field of the relation between religion and developm ent, taking Indonesia as his region of interest, honoring traditions in the department. With respect to the study of Brazilian religion it is important to mention also the work of Allard Willemier Westra on Candom blé in Bahia.

When Blauw retire d in 1976, Matthi eu Schoff eleers was appointed on the chair of Anthro pology of Religion. Schoff eleers had worked as a Catholic missionary in Malawi. Becoming aware of the need for knowledge about the local culture, he discovered the importance of anthro pology. This led him ultimately to do a $\mathrm{PhD}$ in Oxford. When appointed at the department, he continued to work on Malawi, including regular fieldwork. A specific interest he had was the applic ation of the ideas of René Girard to anthro polog ical themes.

Professor Mart Bax, who since 1989 occupied a chair in Political Anthropology, especially religious power formation and processes of state development, made a special contribution to the study of religion in the department. After $\mathrm{PhD}$ fieldwork in Ireland on politics and religion, he had continued his research in the Netherlands,studyingRoman Catholic contexts, and at the end of his careerdoing fieldwork in Medjugorje,former Yugoslavia, on Maria apparitions. Bax coined the term of religious regime, using the approach Norbert Elias had developed on the rise of civilizations and the connection with state formation, emphasizing dependence as a constituting element in religious constellations.

WhenSchoffeleersretired in 1988,André Droogers becamehis successor. Droogers had taught and done research in Congo and Brazil , spending five years in each of these countries. He continued the department's interest in the study of Pentecostalism, stimulating PhD research in this field, initially in Latin America, but later on on a global scale. Among his $\mathrm{PhD}$ students were Bernardo Guerrero from Chile and Daniel Miguez from Argentina. Els Jacobs graduated on a doctoral thesis based on research in Brazil, on the gendered face of CEBs in São Leopoldo, Rio Grande do Sul.

Since 2001 Droogers founded two large research programs, first the program Between Secularisationand Sacralisation(BSS) and in it was joined 
by the research program Conversion Careers and in Global Pentecostalism (CCCP). Both programs comprise $\mathrm{PhD}$ and postdoctoral researchers. Presently, BSS is in the process of finishing the research, whereas CCCP is in the phase of fieldwork and data analysis. Below we will give a short introductioninto these two exciting research programs, devoted to analysing important themes in the study of religion on a local, transnational and comparative level. Droogers also co-founded the Hollenweger Center for the Interdisciplinary Study of Pentecostal and Charismatic Movements. Furthermore, he was involved in the founding of GloPent, the European Network for the Study of Global Pentecostalism. Besides he developed an interest in syncretism, particularly inspired by his stay in Brazil. Droogers is also known for his interest in religion and play, and for his suggestion to use methodological ludism. In his work he pays much attention to the relation between meaning-makingand powerprocesses.

MorerecentlyIslam became an areaof interest,especiallyas a consequence of the emergence of a multicultural society in the Netherlands. The staff members Edien Bartels and Lenie Brouwer have a record of studying Islam both in the Netherlands and in connection to Morocco and Moroccan migration to the Netherlands and other European countries. Martijn de Koning is writing his $\mathrm{PhD}$ dissertation based on anthropological research into the religious identity construction of Moroccan young people in the Netherlands.

Equallyworth mentioning here, is the work of Professor OscarSalemink, who came to the department in 2001 after working five years in Vietnam for the FordFoundation. Salemink is engagedin a researchon religious revival in Southeast Asia, notably Vietnam and Thailand, studying the renewal, reinvention or transformation of local religious practices in the context of modernization, regional integration and globalization. The focus is on "new movements" in order to find out how various groups of people (families, communities, ethnic groups) draw on different religious repertoires in order to create new identities whereby religious content and meaning is linked to political and economic agendas.

Research on religion in Brazil, as initiated by Droogers, was continued in the nineties by Marjode Theije. DeTheije graduated(at Utrecht University)

Debates do NER, Porto AlEgre, ANo 8, N. 11, P. 83-93, jAN./JUn. 2007 
with a dissertationon Catholic lay groups in Garanhuns,Pernambuco, Brazil and latercontinuedcomparing Liberationist Catholicism withthe Charismatic Catholic Movement, in collaborationwith Cecília Mariz. Recently de Theije started new research on gold mining, migration, and religion in Suriname.

Droogers retired in 2006 and was succeeded by Birgit Meyer, who had until then worked at the University of Amsterdam. She had done her $\mathrm{PhD}$ research in Ghana, studying the appropriation of pietisticProtestantism among the Ewe. Her interests include Pentecostalism and the role of media in religion. Before coming to the Vrije Universiteit, she directed the research program 'Modern Mass Media, Religi on and the Imagination of Communities: Different PostcolonialTrajectories in West Africa,Brazil, India and the Caribbean'. Her inaugural lecture on the important role of religious sensations in the study of contemporary religion opened exciting new directions for the anthropological research at the department.

\section{BETWEEN SECULARISATION AND SACRALISATION}

Sociological research into the state of religion in the Netherlands since the 1960s has shown an unmistakable trend of religious decline. Statistics revealed that religious institutions were loosing members very rapidly and that traditional beliefstatements received less and less supportfrom the Dutch population. The last two decades, however,there were clear indications that although the Dutch were becoming less church-oriented; they did not seem to become less religious. Research showed that 'belief in a higher power' was shared by some $70 \%$ of the population and that the interest in phenomena such as astrology, reincarnation and divination techniques was slightly increasing. At the same time, local Christian church life showed resilience, receiving importantinput from repertoiresof evangelicalism, spiritualityand charismatic renewal. Although there was nothing that resembled a revival, the idea of the Netherlands as a deeply secularized country was scientifically unsatisfying. For long the research question had been 'how religious are the Dutch?', but a growing number of researchers from various disciplines suggested that the real question was 'how are the Dutch religious?'. This also 
meant that there had to be a shift from a quantitative approach to more qualitative methods, to show the protean nature of present-day Dutch religiosity. Apart from its theoretical and ethnographic aim, the program has therefore also a methodological emphasis.

To tackle the research problem adequately, the program is structured according to five interrelated themes,i.e. experienœ, identity, morality, ritual, and language. As such, the themes function as a framework to study changes in worldviewand signification. Each respectivetheme is the topic of a specific ethnographic case study, which deals with transformations regarding the theme. At the same time, the other themes are taken into account whenever thishighlights the caseunder study. Forexample, the themeof ritualis situated in a comparative research of liturgical change in Protestant churches, but to understand this transformation, the question of the importance of religious experiencein contemporary Protestantism inevitablypops up. SinceProtestant ritualis dominated by verbalrepertoires, the question of language use becomes equally important. In this sense, the themes operate as specific angles or focal points to track religious change in its many aspects. We will now turn to an overview of the other BSS case studies.

The project on experienceis a case study of Christianspirituality outside the churches in so-called Christian spiritual centers by post-doc researcher Peter Versteeg - who graduated on a thesis on religious experience in a charismatic groupin the Netherlands. Interesting about these spiritual centers is their consumer-orientation, in which religious teaching and techniquesare offered in the form of courses. The centers, mainly with a background in one of the Catholic orders, explicitly stress their Christian inspiration, but are in fact very close to an alternative spiritual ethos, stressing religion as a therapeutic individual quest.

The identity project deals with collective and individual identity formation in relation to processes of significationin an ecumenical church in a city in the West of the Netherlands. The church is a Catholic-Protestant fusion. The research, carried out by post-doc Els Jacobs, also pays attention to this same issue among non-church-going members of this church. Some of the research findings show that believers delibe rately make use of the religiousrepertoires within the church whenever they see these as meaningful 
to their personal life world. This, however, remains largely unrelated to the commitment of people to church life. Whereas the idea of a community of shared experience is cherished, the practical community of believers is in decline.

The research on moral orientations is situated in South Limburg, the utmost Southern part of the Netherlands. This region stands out historically because of its strong Catholic presence. As a result of the waning influence of the churchdifferent kindsof Catholicism can be observed, representingliberal and conservative positions within the religious field. Similarly, alternative religious practices, such as Spiritism are flourishing. In practice, people subscribe to the church hierarchy in liturgical matters, but for their moral orientation they feel alienated from the church and they look for inspiration in different places. Kim Knibbe will defend her $\mathrm{PhD}$ dissertation on this research in 2007.

The language project, carried out by Rhea Hummel, explores the use of language of artists and writers, most of them non-church-going, in relation to signification. Explicit attention receives the way artists use books of all kinds as resources for signification and the construction of worldviews. Different from the other projects where one location is studied, this research uses mainly in-depth interviews and document analys is as methods. Ultimately, several 'worldview' types are constructed on the basis of different use of language. In this way,this research gives us an indication of the role of language in signification, in a context where traditional religious language repertoires have disappeared or have become fragmented.

The overview shows that the orientation of the BSS program is still very much focused on the confines of church religion, with the important exception of the language project. This orientation on changing religion in the churches, however, has not precluded the group of researchers to take into account new perspectives on research. Empirically, this is demonstrated in the latest offshoot of the program, which investigates the market of neopaganpractices, suchas Wiccaand Druidism,in the Netherlands. This research is the $\mathrm{PhD}$ project of Hanneke Minkjan. Theoretically, this is portrayed in our critique of the secularization debate. While not denying the reality of church decline, some developments could best be described as 'beyond' 
secularization. The BSS programshows that post-Christianculture does imply the continuation of religious reper toires in people's lives, albeit operating on very different levels of authority, commitment and belief.

\section{CONVERSION CAREERS AND CULTURE POLITICS}

The last century saw the explosive rise of Pentecostal/charismatic Christianity across the globe. With more than half a billion people adhering to a type of Pentecostal belief and practice, this unprecedented growth still continues into the present age. Pentecostalism did not escape the attention of a wide range of scholars from different disciplines and many studies have been written on the nature and attraction of this type of religiosity. However, up till now comparative studies about the specific appeal of Pentecostalism in very different social contexts (or its relative stagnation in other contexts) have not been undertaken. The research program CCCP attempts to explore this void from a social scientificapproach, focusing on a central characteristic of Pentecostal discourse and practice: conversion. CCCP executes the ambitious plan of studying Pentecostal varieties within four continents, combining two relevant research themes. Firstly, the conceptof the "conversion career' is meant to highlight the process of people's affiliations to Pentecostal belief and practice. It is an analytical angle meant to arrive at a more in-depth view of people's motivations for religious change and their passage through phases of religiousadherence. Importantin this respect is that the "conversion careers' concept focuses on beliefs and practice rather than church membership, the latter being a specific marker of religious affiliation within a much more complex process of change.

'Culture politics' refers in this case to the way churches position themselves in relation to a social and cultural context. It includes communicative and other strategies that churches adopt to act upon the social reality of which they are part. Often this concerns processes of differentiation, in which churches criticize 'the world', offering maze ways and alternatives for the socially given. As such, 'culture politics' link up with individual 'conversion careers' because it affects the way in which churches try to reach an audience,

Debates do NER, Porto Alegre, Ano 8, N. 11, P. 83-93, JAN./Jun. 2007 
but it affects equally the way in which church members (are allowed to) engage in society.

The case studies in this program demonstrate different ways of how conversion and cultureare interrelated,showing the specificitiesof a particular locale, Japan/Korea, Mozambique, Nicaragua and The Netherlands respectively. Besides the two themes, all projects are concerned with the role of transnational flows of beliefs and practices.

The East Asia project deals with the transmission and contextualization of the Yoido Full Gospel Church in Japan and Korea. Yoido is a successful Korean initiated Pentecostal movement with a considerable influence on Pentecostalism worldwide. In Japan, however, Pentecostalism is the religion of a small minority, viewed by many Japanese as a faith for Korean migrants. Important issues in this case study are the tense post-colonial relationships between Korea and Japan, and the difference between the Japanese religious habitus of eclectic non-commitment against the high commitment demanded by Yoido. The project is carried out in Tokyo and Seoul. This $\mathrm{PhD}$ project is carried out by Ikuya Noguchi.

'Brazilian' Pentecostal churches are thriving in Maputo, Mozambique, research site of the Southern Africa project that is carried out by $\mathrm{PhD}$ student Linda van de Kamp.The Brazilianconnection gives Pentecostalism a distinct transnationalcultural style that has an affinity with the lifestyles of the newly emerging urban middle classes. Through this style, phrased in an assertive and contemporary style,Pentecostalchurches offer viable identityalternatives in post-socialist, post-warMozambique. Relatedto this is the way Pentecostal churches provide space for healing and empowerment, which is especially attractive to women.

The LatinAmerica project, of post-doc researcher HenriGooren, focuses on the religiousmarket in a neighborhood in Managua,Nicaragua. Particular emphasis is given to the way in which a Catholic group and a Pentecostal church in a low-income neighborhood position themselves in relation to poverty, machismo and 'syncretic' religion.

The European project in fact comprises two projects. The first is a comparison of an evangelical 'seeker' church and a radical neo-Pentecostal 
churchin the Amsterdam region(The Netherlands), by $\mathrm{PhD}$ student Miranda Klaver. Both churches show similarities in terms of organization, cultural style and an explicit reflection on surrounding culture. Both are also successful in attracting new members. Yet, what looks similar at first glance shows somecrucial differencesin discourse and practice, affecting the religious careers of believers in profound ways. Confirmation vs. revelation, stage drama vs. ecstatic drama, and social accommodation vs. metaphysical dualism form important markers of difference here. The second project, of $\mathrm{PhD}$ student Regien Smit, is also carried out in the Netherlands. The case study is a comparison of two Portuguese speaking Pentecostal migrant churches in Rotterdam, one with members of predominantly Angolan origin, the other predominantly Brazilian. The focus of the research is how in both churches spiritual power is expressed and formed and how this affects dynamics of social power in both churches. A particular emphasis is given to the relation between different forms of power and prosperity teaching.

\section{FINAL CONSIDERATIONS}

Now eight of the current $\mathrm{PhD}$ students are a member of the BSS or CCCPgroups, although thereare also $16 \mathrm{PhD}$ students working on individual research projects. Of these last students, several have projects that deal with religiousthemes too, such as 'Cosmopolitanisingand PoliticisingFalun Gong Membership and Practices' (Scott Dalby, started 2006), 'Transnational Religious Networks and Protestant Conversion among the Hmong in Northern Vietnam' (Tam Ngo, started 2005), and 'Symbolic, Material and Personal Exchanges between Dutch and Brazilian Actors through Kerkinactie's Network' (João Rickli, started 2005). Furthermore, each year some 25 students conclude theirmaster studies at the departmentof Social and Cultural Anthropology and they too often write their theses on religious groups or related topics. Within the scope of this article it is not possible to mention these. The anthropological study of religion is a major theme at the Vrije Universiteit since the founding of the department, that already produced many books and articles, and for the future this specialization promises many more fruits and offshoots.

Debates do NER, Porto Alegre, ano 8, N. 11, P. 83-93, JAN./Jun. 2007 


\section{REFERENCES}

Weblinks

Department of Social and Cultural Anthropology, Vrije Universiteit Amsterdam: $<\underline{\text { http: } / / \text { www.fsw.vu.nl/english }>\text {. }}$

Between Secularization and Sacralization (BSS): < $\underline{\text { http://www.fsw.vu.nl/ }}$ onderzoek/tsr $>$.

Conversion Careers and Culture Politics in Global Pentecostalism(CCCP): $<$ http://pentecost.religionresearch.ong $>$.

Europe an Research Network on Global Pent ecostalis m: < http:// www.glopent.net/>.

Holle nweger Center for Pentecostal Studies: < http://www.hollenwe gercenter.net>. 
